\title{
Disseminated toxoplasmosis in Antillean manatees Trichechus manatus manatus from Puerto Rico
}

\author{
Gregory D. Bossart ${ }^{1,2, *}$, Antonio A. Mignucci-Giannoni ${ }^{3}$, \\ Antonio L. Rivera-Guzman ${ }^{3}$, Nilda M. Jimenez-Marrero ${ }^{4}$, Alvin C. Camus ${ }^{5}$, \\ Robert K. Bonde ${ }^{6}$, Jitender P. Dubey ${ }^{7}$, John S. Reif ${ }^{8}$
}

\author{
${ }^{1}$ Georgia Aquarium, 225 Baker Street Northwest, Atlanta, Georgia 30313, USA \\ ${ }^{2}$ Department of Pathology, Miller School of Medicine, University of Miami, Miami, Florida 33136, USA \\ ${ }^{3}$ Puerto Rico Manatee Conservation Center, Inter American University of Puerto Rico, San Juan 00936, Puerto Rico \\ ${ }^{4}$ Bureau of Fish and Wildlife, Puerto Rico Department of Natural and Environmental Resources, San Juan 00936, Puerto Rico \\ ${ }^{5}$ Department of Pathology, College of Veterinary Medicine, University of Georgia, Athens, Georgia 30602, USA \\ ${ }^{6}$ US Geological Survey, Southeast Ecological Science Center, Sirenia Project, Gainesville, Florida 32653, USA \\ ${ }^{7}$ US Department of Agriculture, Agricultural Research Service, Animal and Natural Resources Institute, \\ Animal Parasitic Diseases Laboratory, Beltsville, Maryland 20705, USA \\ ${ }^{8}$ Department of Environmental and Radiological Health Sciences, College of Veterinary Medicine and Biomedical Sciences, \\ Colorado State University, Fort Collins, Colorado 80523, USA
}

\begin{abstract}
Necropsies were conducted on 4 Antillean manatees Trichechus manatus manatus that were stranded in single events on the coastal beaches of Puerto Rico from August 2010 to August 2011. Three manatees were emaciated and the gastrointestinal tracts were devoid of digesta. Microscopically, all manatees had severe widespread inflammatory lesions of the gastrointestinal tract and heart with intralesional tachyzoites consistent with Toxoplasma gondii identified by histological, ultrastructural and immunohistochemical techniques. The gastrointestinal lesions included severe, multifocal to diffuse, chronic-active enteritis, colitis and/or gastritis often with associated ulceration, necrosis and hemorrhage. Enteric leiomyositis was severe and locally extensive in all cases and associated with the most frequently observed intralesional protozoans. Moderate to severe, multifocal, chronic to chronic-active, necrotizing myocarditis was also present in all cases. Additionally, less consistent inflammatory lesions occurred in the liver, lung and a mesenteric lymph node and were associated with fewer tachyzoites. Sera $(\mathrm{n}=30)$ collected from free-ranging and captive Puerto Rican manatees and a rehabilitated/released Puerto Rican manatee from 2003 to 2012 were tested for antibodies for T. gondii. A positive T. gondii antibody titer was found in 2004 in 1 (3\%) of the free-ranging cases tested. Disease caused by T. gondii is rare in manatees. This is the first report of toxoplasmosis in Antillean manatees from Puerto Rico. Additionally, these are the first reported cases of disseminated toxoplasmosis in any sirenian. The documentation of 4 cases of toxoplasmosis within one year and the extremely low seroprevalence to $T$. gondii suggest that toxoplasmosis may be an emerging disease in Antillean manatees from Puerto Rico.
\end{abstract}

KEY WORDS: Toxoplasma gondii - Sirenian - Gastroenteritis - Enterocolitis - Myocarditis · Emerging disease

Resale or republication not permitted without written consent of the publisher

\section{INTRODUCTION}

Sirenians are large herbivorous aquatic mammals that live in tropical and subtropical regions, and include one species of dugong (Dugong dugon), generally found in coastal regions of the Indopacific; the
West African manatee Trichechus senegalensis, found in coastal waters, rivers and lakes of western and west central Africa; the Amazonian manatee Trichechus inunguis, which is restricted to the freshwater rivers and lakes of the Amazon basin; and the West Indian manatee Trichechus manatus 
(Aragones et al. 2012). The West Indian manatee has 2 subspecies: the Antillean manatee Trichechus manatus manatus, found in the West Indies, the Caribbean and coastal waters of Mexico, Central America and northeastern South America (Self-Sullivan \& Mignucci-Giannoni 2012), and the Florida manatee Trichechus manatus latirostris, found in coastal waters and rivers of the southeastern US and the Gulf of Mexico, as far west as the Texas coast (Deutsch \& Reynolds 2012). All are considered by the International Union for the Conservation of Nature (IUCN) to be vulnerable or endangered with extinction (Deutsch et al. 2008). Based on clinicopathologic findings, Florida and Antillean manatees appear to be remarkably resistant to natural infectious disease and the sub-lethal effects of traumatic injury (Buergelt et al. 1984, Bossart 2001, Bossart et al. 2003, 2004). These disease-resistant traits of manatees may partially result from a remarkably efficient and responsive immune system (Bossart 1999).

Limited seroprevalence studies have demonstrated Toxoplasma gondii antibodies in Amazonian manatees from Brazil but not in Antillean manatees from Mexico (Alvarado-Esquivel et al. 2012, Mathews et al. 2012). However, based on past pathologic studies, clinical toxoplasmosis is a rare disease in manatees (Buergelt et al. 1984, Bossart et al. 2003, 2004, Dubey et al. 2003). Disseminated toxoplasmosis in manatees has not been reported. The purpose of this report is to describe the pathologic features of a cluster of disseminated toxoplasmosis in Antillean manatees from Puerto Rico.

\section{MATERIALS AND METHODS}

Necropsies were conducted on 4 Antillean manatees (1 subadult male, 1 subadult female and 2 adult females) that were singularly found stranded and dead on the coastal beaches of Puerto Rico (Añasco, Carolina, Dorado and Loíza municipalities) from August 2010 to August 2011. Manatees were necropsied by the staff of the Department of Natural and Environmental Resources' Marine Mammal Rescue Program and the Puerto Rico Manatee Conservation Center (PRMCC) at the Inter American University of Puerto Rico, as part of a collaborative program with the Georgia Aquarium to establish baseline pathologic findings in manatees from Puerto Rico. A complete necropsy, following an established procedure (Bonde et al. 1983, 2012), was performed on each carcass. Age classification was based on standardized total straight length measurements specific to Antillean manatees: adult $(>225 \mathrm{~cm})$, subadult $(176$ to $225 \mathrm{~cm})$ and calf $(<176 \mathrm{~cm})$ (Mignucci-Giannoni et al. 2000). Tissue sections from the lung, heart, liver, spleen, superficial and deep lymph nodes, stomach, pancreas, small intestine, colon, kidney and reproductive tract were collected for histologic examination from all manatees. Central nervous system tissue was not collected due to logistical limitations. Tissues were placed in $10 \%$ neutral buffered formalin, routinely processed, embedded in paraffin, sectioned at $5 \mu \mathrm{m}$ and stained with hematoxylin and eosin. All manatees had minimum post-mortem decomposition.

Formalin-fixed portions of heart and intestine were examined by transmission electron microscopy using standard embedding procedures. Ultrathin sections were obtained with an ultramicrotome, stained with uranyl acetate and lead citrate, and subsequently examined as previously described (Bossart et al. 2002).

Immunohistochemical (IHC) staining for Toxoplasma gondii and for cetacean morbillivirus (CMV) antigen was performed in formalin-fixed, paraffinembedded tissue sections of lung, heart, intestine, liver, spleen and lymph node as previously described (Dubey \& Hamir 2000, Dubey et al. 2003, Bossart et al. 2010). Known T. gondii- and CMV-infected tissues were used as positive controls for each test and duplicate tissue sections were also reacted with an unrelated monoclonal antibody as negative controls. CMV IHC staining was performed because coinfection with $T$. gondii and CMV was recently reported in a cetacean (Mazzariol et al. 2012) and because disseminated toxoplasmosis is closely associated with a compromised immune system in other species (Dubey \& Beattie 1988, Brown et al. 2005, Dubey 2010). Fresh tissue was not available for molecular studies.

Sera were tested for Toxoplasma gondii antibodies from 27 free-ranging Antillean manatees (22 adults and 5 subadults) collected as part of a telemetry/ health assessment project in Puerto Rico from 2003 to 2005. Sera also were tested from 2 Puerto Rico captive manatees (1 Antillean manatee calf and 1 Florida manatee adult) sampled in 2011 and 1 rehabilitated/ released adult Antillean manatee sampled as part of a $1 \mathrm{yr}$ post-release health assessment in 2011 and then again in 2012. Prior to testing, sera were kept frozen at $-80^{\circ} \mathrm{C}$. Detection of $T$. gondii antibodies was performed by the modified agglutination test (Dubey \& Desmonts 1987). The sera were examined at dilutions of $1: 25,1: 50$ and 1:500, and a titer of $1: 25$ 
was used as an indicator of exposure to $T$. gondii (Dubey et al. 2003). Negative and positive controls were used in all reactions.

\section{RESULTS}

Grossly, 3 manatees had advanced emaciation characterized by prominent head, neck, scapular, rib and peduncular skeletal features and the ventral abdomens had multiple longitudinal linear folds and a sunken-in appearance. In these 3 cases, the stomachs and duodenal ampullae contained little or no ingesta and the large intestines were largely devoid of fecal matter. The remaining manatee's body condition was considered normal. The gastrointestinal tracts of all 4 manatees had multifocal mucosal ulceration, hemorrhage and/or congestion. Additionally, pulmonary congestion, hemorrhage and/or bronchial edema were consistent findings in all animals. The 2 adult females had few nasal trematodes consistent with Pulmonicola cochleotrema and the large intestine of the male manatee had abundant luminal trematodes consistent with Chiorchis groschafti (Bonde et al. 1983).

Microscopically, widespread inflammation was found in the heart and gastrointestinal tract of all 4 manatees. Additionally, less consistent inflammatory lesions occurred in the liver ( 2 cases), lung (1 case) and mesenteric lymph node (1 case). All of the above inflammatory lesions had intralesional tachyzoites consistent with Toxoplasma gondii.

The gastrointestinal lesions included enteritis (4 cases), colitis ( 1 case) and gastritis (1 case) and were characterized by severe multifocal or diffuse infiltrates of neutrophils, macrophages, lymphocytes and occasional plasma cells of the lamina propria, submucosa and smooth muscle, often with associated mucosal ulceration, necrosis and hemorrhage. The gastrointestinal inflammation was transmural in 2 cases and was associated with severe chronic-active peritonitis in 1 case. Enteric leiomyositis was particularly severe and locally extensive in all cases and associated with the most frequently observed intralesional protozoans (Fig. 1A).

The myocardial lesions were characterized by moderate to severe multifocal necrosis with infiltrates of neutrophils (1 case), neutrophils and macrophages ( 2 cases) or lymphocytes and macrophages (1 case) (Fig. 1B). Myocarditis was associated with moderate multifocal chronic pericarditis in 2 cases. Protozoans were observed in lower numbers in the heart compared to the gastrointestinal tracts.

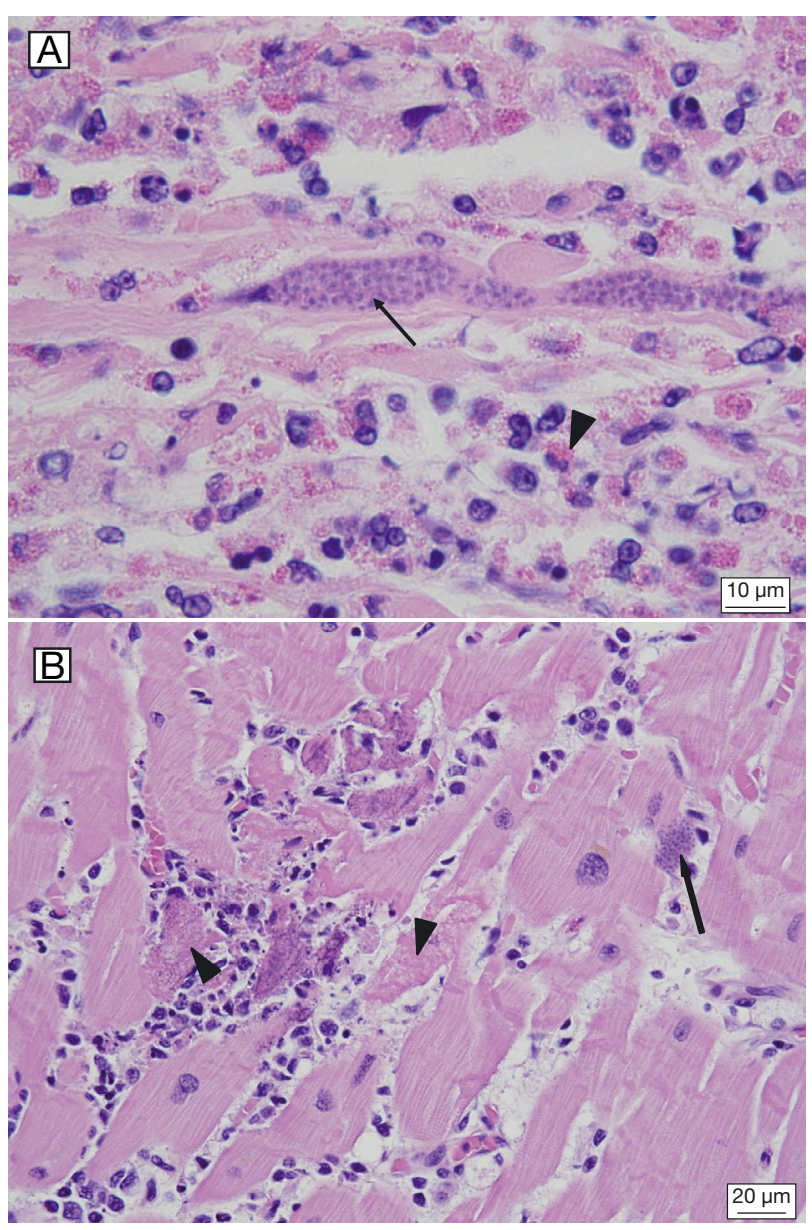

Fig. 1. Trichechus manatus manatus. Lesions from an Antillean manatee from Puerto Rico. Hematoxylin and eosin stain (H\&E). (A) Section of enteric smooth muscle with infiltrates of many typical manatee neutrophils with eosinophilic prominence (arrowhead) associated with Toxoplasma gondii tachyzoites (arrow). (B) Section of myocardium with mononuclear cell infiltration, multifocal necrosis (arrowheads) and T. gondii tachyzoites (arrow)

Finally, moderate to severe diffuse chronic-active necrotizing hepatitis (2 cases), severe diffuse suppurative bronchointerstitial pneumonia (1 case) and moderate multifocal acute necrotizing lymphadenitis (1 case) were associated with fewer intralesional protozoans. Protozoans also were observed in the pancreas of 1 case that had acinar atrophy.

Other microscopic lesions not associated with protozoans were common. Widespread severe pancreatic acinar atrophy characterized by loss of zymogen granules, acinar cell shrinkage and increased cytoplasmic basophilia was present in 3 cases. Mild multifocal chronic interstitial nephritis was present in 3 cases. Less consistent lesions were moderate lymphoid depletion of lymph nodes ( 2 cases) and moderate multifocal acute splenitis (1 case). 


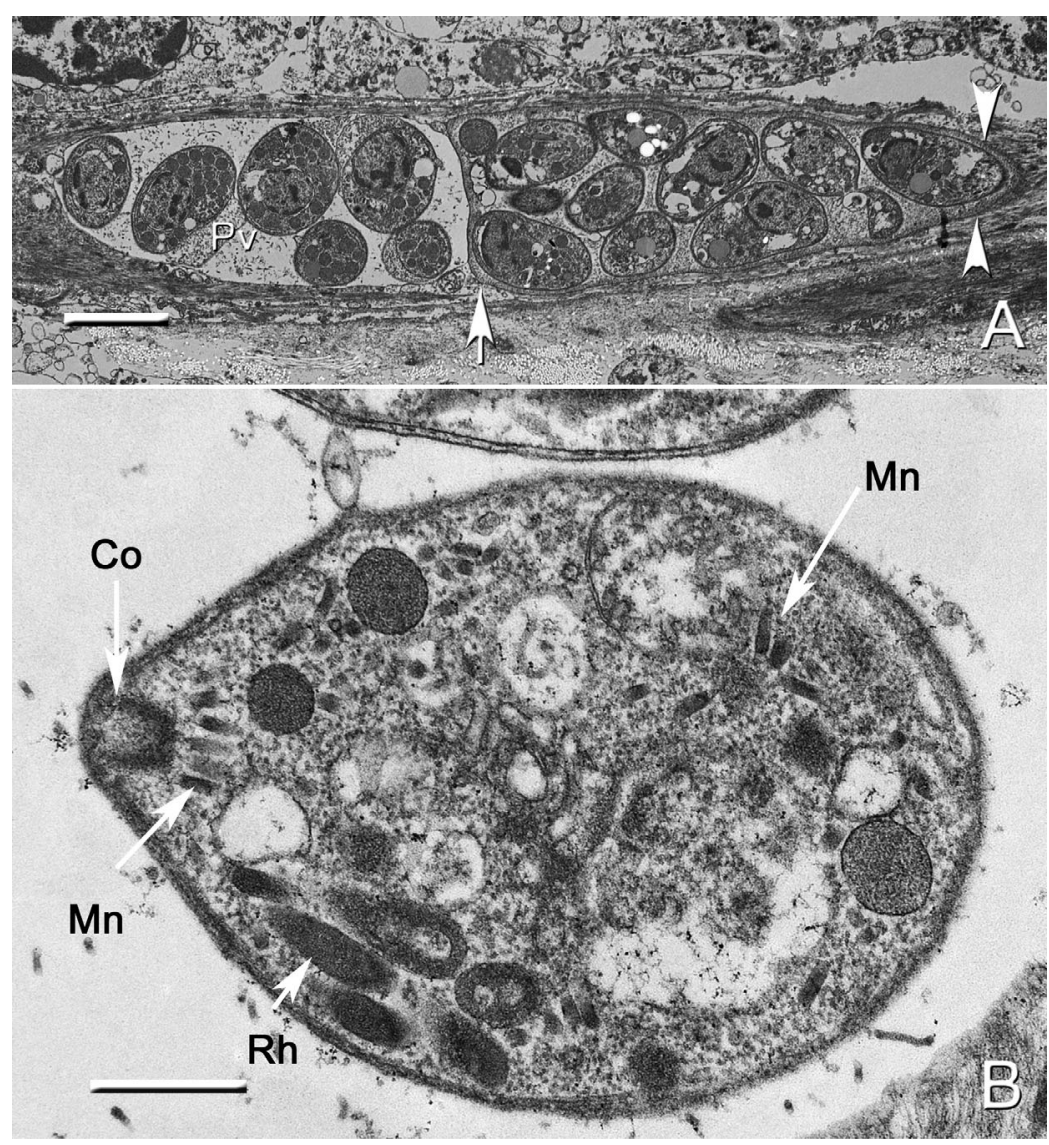

Fig. 2. Trichechus manatus manatus. Transmission electron microscopy of tachyzoites from enteric lesions. (A) Two intracellular groups apparently with one host cell (arrow), tachyzoites on the left and a tissue cyst on the right. Arrowheads point to tissue cyst wall. Note a prominent parasitophorous vacuole $(\mathrm{Pv})$ containing numerous intravacuolar tubules in the group of tachyzoites. Scale bar $=4 \mu \mathrm{m}$. (B) Conoidal end of a tachyzoite showing a conoid (Co), a few micronemes $(\mathrm{Mn})$ and rhoptries (Rh). Scale bar $=1 \mu \mathrm{m}$

\section{DISCUSSION}

Toxoplasma gondii infection in aquatic mammals is important because some species are considered as sentinels for aquatic ecosystem $T$. gondii oocyst contamination. Toxoplasmosis can cause significant mortality (Dubey et al. 2003, Bossart 2011) in marine mammals, as shown in studies of southern sea otters Enhydra lutris nereis and other aquatic mammals (Buergelt \& Bonde 1983, Di Guardo et al. 2011, Dubey et al. 2003, Miller et al. 2002, 2008, Santos et al. 2011, Simon et al. 2011). Felids are the definitive hosts for $T$. gondii since they shed viable oocysts in feces that contaminate the environment. The ingestion of oocysts in contaminated food or water and the ingestion of $T$. gondiiinfected tissues are the 2 main sources of postnatal T. gondii infection. Because only domestic cats and other felids are known to serve as definitive hosts for T. gondii, infections in aquatic mammals suggest a land to water flow of the parasite (Miller et al. 2002, Shapiro et al. 2012). Oocysts from cat feces may wash into freshwater streams, runoffs and seawater, where they can survive for at least 24 mo and serve as a source of infection via transport hosts (Lindsay \& Dubey 2009).
Ultrastructurally, both tachyzoites and tissue cysts were observed, sometimes within the same cell (Fig. 2). Tachyzoites were located in parasitophorous vacuoles that contained numerous intravacuolar tubules (Fig. 2A). Although protozoans were partly autolyzed, a conoid, several micronemes and rhoptries with electron-lucent contents could be recognized (Fig. 2B). Tissue cysts had a clearly defined cyst wall (Fig. 2A).

Strong positive IHC staining of the observed tachyzoites for Toxoplasma gondii antigen was present in all tested tissues (Fig. 3). No CMV antigen was observed in IHC stained tissues.

A single serum sample from an adult male Antillean manatee captured in Puerto Rico in 2004 as part of a telemetry/health assessment project had a low Toxoplasma gondii titer of 1:25. All other manatee sera were negative at 1:25, 1:50 and 1:500 dilutions.

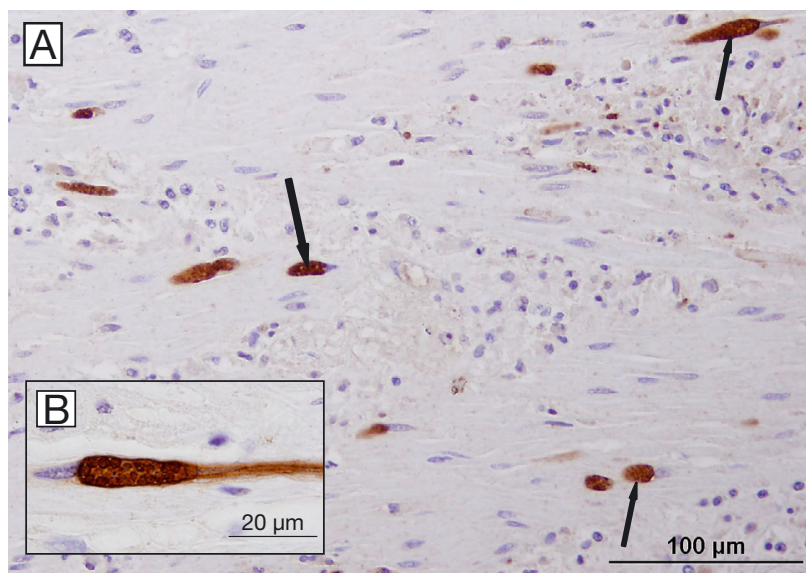

Fig. 3. Trichechus manatus manatus. (A) Positive immunohistochemical stain showing intralesional Toxoplasma gondii tachyzoites (arrows) associated with enteric leiomyositis. (B, inset) Higher magnification showing intense immunohistochemical staining (brown signal) 
Interestingly, Dubey et al. (2007) documented a mouse-virulent $T$. gondii in feral cats from a remote uninhabited island off Puerto Rico. Molecular characterization of the T. gondii in the Antillean manatees from this report was not carried out, so it remains to be determined whether the Puerto Rican cat and manatee $T$. gondii are related.

Toxoplasmosis is a rare disease in manatees; the 2 previously reported cases consisted of a manatee calf in Florida with central nervous system infection and an adult Antillean manatee from Guyana with lesions in the heart (Buergelt \& Bonde 1983, Bossart 2001). The Florida manatee calf case had Toxoplasma gondii tissue cysts in sections of brain with associated nonsuppurative meningoencephalitis (Buergelt \& Bonde 1983). It was uncertain whether T. gondii was the primary cause of death because tachyzoites were not seen; thus, the cysts observed may have been an incidental finding (Dubey et al. 2003). The case reported in the Antillean manatee from Guyana had intralesional $T$. gondii tachyzoites in association with a severe multifocal necrotizing myocarditis (Bossart 2001). In both of the previously reported cases, protozoal infection was not disseminated and was limited to a single organ system.

The mechanism of Toxoplasma gondii infection in manatees is intriguing because manatees are exclusively herbivorous, feeding on aquatic plants. Thus, ingestion of $T$. gondii-infected meat or animal tissue is unlikely. As in sea otters, land-based surface runoff may be a significant risk factor for $T$. gondii infection in Puerto Rican manatees with oocysts washing into freshwater streams and coastal waters via effluents contaminated by cat excrement. Since manatees are known to habituate more urbanized areas, they are likely to be exposed to effluents contaminated with cat feces (Buergelt \& Bonde 1983). The cases reported herein were all in close proximity $(0.4$ to $3.5 \mathrm{~km}$ ) to 3 main rivers (Río Grande de Añasco, Río de la Plata and Río Grande de Loíza) and one urban estuary (Laguna La Torrecilla, part of the San Juan Bay estuary).

From 1990 to 2006, an average of 7 manatees were found dead each year in Puerto Rico $(n=121)$. The leading causes of mortality were of natural origin $(44 \%)$, consisting predominantly of orphaned dependent calves $(23 \%)$ and disease $(17 \%)$, followed by anthropogenic causes ( $29 \%$ ) including watercraft strike $(20 \%)$, poaching $(5 \%)$ and suspected pollution ( $2 \%$ ) (Bonde et al. 2012). This is the first report of toxoplasmosis in Antillean manatees from Puerto Rico. Additionally, these are the first reported cases of intralesional Toxoplasma gondii tachyzoites associ- ated with disseminated disease in a sirenian. The documentation of 4 cases of toxoplasmosis within a year and the extremely low prior seroprevalence to $T$. gondii suggest that toxoplasmosis may be an emerging disease in Antillean manatees from Puerto Rico. In addition to causing mortality in Puerto Rican manatees, $T$. gondii is a zoonotic pathogen that infects up to one-third of the human population (Hill \& Dubey 2002). However, disseminated clinical disease and mortality in humans occurs most often in immunocompromised patients (Dubey \& Beattie 1988, Brown et al. 2005, Dubey 2010). Thus, the possibility of a similar immunologic mechanism in disease pathogenesis and dissemination in manatees cannot be ruled out. This report raises questions about the prevalence of $T$. gondii infection in feral cats in Puerto Rico and the mechanism of transfer of this terrestrial parasite to the aquatic environment and Antillean manatee. Further studies to address these questions are essential to fully understand the health risks to endangered Antillean manatees and the human population of Puerto Rico. Investigation into the origins and pathways of protozoal infections of manatees will provide a better understanding of terrestrial parasite flow and the emergence of disease at the interface between wildlife, domestic animals and humans.

Acknowledgements. Carcass salvage was conducted under the authority of Puerto Rico's Department of Natural and Environmental Resources and the US Fish and Wildlife Service permit number M791721-4, issued to the US Geological Survey, Sirenia Project. We gratefully acknowledge the assistance of the Puerto Rico Manatee Conservation Center technicians, students and volunteers in tending to the stranding events and collecting samples, particularly C. Rivera and L. Falcón. This research was funded in part by a grant from the Commonwealth of Puerto Rico Legislature and the Georgia Aquarium. Any use of trade, product or firm names is for descriptive purposes only and does not imply endorsement by the US Government.

\section{LITERATURE CITED}

Alvarado-Esquivel C, Sánchez-Okrucky R, Dubey JP (2012) Serological evidence of Toxoplasma gondii infection in captive marine mammals in Mexico. Vet Parasitol 184: 321-324

Aragones LV, Lawler I, Marsh H, Domning D, Hodgson A (2012) The role of Sirenians in aquatic ecosystems. In: Hines EM, Reynolds JE, Aragones LV, Mignucci-Giannoni AA, Marmontel M (eds) Sirenian conservation: issues and strategies in developing countries. University Press of Florida, Gainesville, FL, p 4-11

Bonde R, O'Shea T, Beck C (1983) A manual of procedures for the salvage and necropsy of carcasses of the West Indian manatee (Trichechus manatus). Document No. 
PB83255273. National Technical Information Service, Springfield, VA, p 1-175

Bonde RK, Mignucci-Giannoni AA, Bossart GD (2012) Sirenian pathology and mortality assessment. In: Hines EM, Reynolds JE, Aragones LV, Mignucci-Giannoni AA, Marmontel M (eds) Sirenian conservation: issues and strategies in developing countries. University Press of Florida, Gainesville, FL, p 148-156

Bossart GD (1999) The Florida manatee: on the verge of extinction? J Am Vet Med Assoc 214:1178-1183

Bossart GD (2001) Manatees. In: Dierauf L, Gulland F (eds) Marine mammal medicine. CRC Press, Boca Raton, FL, p 939-960

Bossart GD (2011) Marine mammals as sentinel species for oceans and human health. Vet Pathol 48:676-690

Bossart GD, Ewing R, Lowe M, Sweat M and others (2002) Viral papillomatosis in Florida manatees (Trichechus manatus latirostris). Exp Mol Pathol 72:37-48

Bossart GD, Meisner R, Rommel SA, Ghim S, Jenson AB (2003) Pathological features of the Florida manatee cold stress syndrome. Aquat Mamm 29:9-17

Bossart GD, Meisner R, Rommel SA, Lightsey JA, Varela RA, Defran RH (2004) Pathologic findings in Florida manatees (Trichechus manatus latirostris). Aquat Mamm 30: 434-440

> Bossart GD, Reif JS, Schaefer AM, Goldstein J, Fair PA, Saliki JT (2010) Morbillivirus infection in free-ranging Atlantic bottlenose dolphins (Tursiops truncatus) from the southeastern United States: seroepidemiologic and pathologic evidence of subclinical infection. Vet Microbiol 143:160-166

Brown AS, Schaefer CA, Quesenberry CP Jr, Liu L, Babulas VP, Susser ES (2005) Maternal exposure to toxoplasmosis and risk of schizophrenia in adult offspring. Am J Psychiatry 162:767-773

- Buergelt CD, Bonde RK (1983) Toxoplasmic meningoencephalitis in a West Indian manatee. J Am Vet Med Assoc 183:1294-1296

Buergelt CD, Bonde RK, Beck CA, O'Shea TJ (1984) Pathologic findings in manatees in Florida. J Am Vet Med Assoc 185:1331-1334

Deutsch CJ, Reynolds JE (2012) Florida manatee status and conservation issues. In: Hines EM, Reynolds JE, Aragones LV, Mignucci-Giannoni AA, Marmontel M (eds) Sirenian conservation: issues and strategies in developing countries. University Press of Florida, Gainesville, FL, p 23-35

Deutsch CJ, Self-Sullivan C, Mignucci-Giannoni AA (2008) Trichechus manatus. IUCN Red List of Threatened Species, Version 2011.2. Available at www.iucnredlist.org

> Di Guardo G, Di Cesare A, Otranto D, Casalone C and others (2011) Genotyping of Toxoplasma gondii isolates in meningo-encephalitis affected striped dolphins (Stenella coeruleoalba) from Italy. Vet Parasitol 183:31-36

Dubey JP (2010) Toxoplasmosis of animals and humans, 2nd edn. CRC Press, Boca Raton, FL

Dubey JP, Beattie CP (1988) Toxoplasmosis of animals and man. CRC Press, Boca Raton, FL

> Dubey JP, Desmonts G (1987) Serological responses of

Editorial responsibility: Michael Moore,

Woods Hole, Massachusetts, USA equids fed Toxoplasma gondii oocysts. Equine Vet J 19: 337-339

- Dubey JP, Hamir AN (2000) Immunohistochemical confirmation of Sarcocystis neurona infections in raccoons, mink, cat, skunk and pony. J Parasitol 86:1150-1152

Dubey JP, Zarnke R, Thomas NJ, Wong SK and others (2003) Toxoplasma gondii, Neospora caninum, Sarcocystis neurona, and Sarcocystis canis-like infections in marine mammals. Vet Parasitol 116:275-296

> Dubey JP, López-Torres NY, Sundar N, Velmurugan GV, Kwok OC, Hill R, Su C (2007) Mouse-virulent Toxoplasma gondii from feral cats in Mona Island, Puerto Rico. J Parasitol 93:1365-1369

Hill D, Dubey JP (2002) Toxoplasma gondii: transmission, diagnosis and prevention. Clin Microbiol Infect 8: 634-640

Lindsay DS, Dubey JP (2009) Long-term survival of Toxoplasma gondii sporulated oocysts in seawater. J Parasitol 95:1019-1020

Mathews PD, da Silva VMF, Rosas FCW, d'Affonseca Neto JA and others (2012) Occurrence of antibodies to Toxoplasma gondii and Lepstospira spp in manatees (Trichechus inunguis) of the Brazilian Amazon. J Zoo Wildl Med 43:85-88

> Mazzariol S, Marcer F, Mignone W, Serracca L and others (2012) Dolphin morbillivirus and Toxoplasma gondii coinfection in a Mediterranean fin whale (Balaenoptera physalus). BMC Vet Res 8:20 doi:10.1186/1746-6148-8-20

Mignucci-Giannoni AA, Montoya-Ospina RA, JimenezMarrero NM, Rodriguez-Lopez MA, Williams EH Jr, Bonde RK (2000) Manatee mortality in Puerto Rico. Environ Manag 25:189-198

Miller MA, Gardner IA, Kreuder C, Paradies DM and others (2002) Coastal freshwater runoff is a risk factor for Toxoplasma gondii infection of southern sea otters (Enhydra lutris nereis). Int J Parasitol 32:997-1006

Miller MA, Miller WA, Conrad PA, James ER and others (2008) Type X Toxoplasma gondii in a wild mussel and terrestrial carnivores from coastal California: new linkages between terrestrial mammals, runoff and toxoplasmosis of sea otters. Int J Parasitol 38:1319-1328

Santos PS, Albuqurque GR, Da Silva VM, Martin AR and others (2011) Seroprevalence of Toxoplasma gondii in free-living Amazon river dolphins (Inia geoffrensis) from central Amazon, Brazil. Vet Parasitol 183:171-173

Self-Sullivan C, Mignucci-Giannoni AA (2012) West Indian manatees (Trichechus manatus) in the Wider Caribbean Region. In: Hines EM, Reynolds JE, Aragones LV, Mignucci-Giannoni AA, Marmontel M (eds) Sirenian conservation: issues and strategies in developing countries. University Press of Florida, Gainesville, FL, p 36-46

Shapiro K, Miller M, Mazet J (2012) Temporal association between land-based runoff events and california sea otter (Enhydra lutris nereis) protozoal mortalities. J Wildl Dis 48:394-404

> Simon A, Chambellant M, Ward BJ, Simard M and others (2011) Spatio-temporal variations and age effect on Toxoplasma gondii seroprevalence in seals from the Canadian Arctic. Parasitology 138:1362-1368

Submitted: July 16, 2012; Accepted: August 27, 2012

Proofs received from author(s): October 30, 2012 